doi:10.1016/j.envpol.2005.07.014

Copyright @ 2005 Elsevier Ltd All rights reserved.

\title{
Functional recovery of biofilm bacterial communities after copper exposure
}

\section{Marie-Elène Y. Boivin ${ }^{a, b, *}$, Boris Massieux ${ }^{c}$, Anton M. Breure ${ }^{a}$, Gerdit D. Greve $^{a, b}$, Michiel Rutgers $^{a}$ and Wim Admiraal ${ }^{d}$}

${ }^{a}$ National Institute for Public Health and the Environment, P.O. Box 1, 3720 BA

Bilthoven, The Netherlands

${ }^{\text {b}}$ Vrije Universiteit, Department of Animal Ecology, De Boelelaan 1085, $1081 \mathrm{HV}$

Amsterdam, The Netherlands

${ }^{\mathrm{c}}$ Netherlands Institutes of Ecology, Centre for Limnology, Rijkstraatweg 6, 3631

AC Nieuwersluis, The Netherlands

dUniversity of Amsterdam, Department of Aquatic Ecology and Ecotoxicology, Kruislaan 320, 1098 SM Amsterdam, The Netherlands

\footnotetext{
* Corresponding author. National Institute for Public Health and the Environment, P.O. Box 1, 3720 BA Bilthoven, The Netherlands. Tel.: +31 03274 4109; fax: +31032744401 .
}

\begin{abstract}
Potential of bacterial communities in biofilms to recover after copper exposure was investigated. Biofilms grown outdoor in shallow water on glass dishes were exposed in the laboratory to $0.6,2.1,6.8 \mu \mathrm{mol} / \mathrm{l}$ copper amended surface water and a reference and subsequently to un-amended surface water. Transitions of bacterial communities were characterised with denaturing gradient gel electrophoresis (DGGE) and community-level physiological profiles (CLPP). Exposure to $6.8 \mu \mathrm{mol} / \mathrm{l}$ copper provoked distinct changes in DGGE profiles of bacterial consortia, which did not reverse upon copper depuration. Exposure to 2.1 and $6.8 \mu \mathrm{mol} / \mathrm{l}$ copper was found to induce marked changes in CLPP of bacterial communities that proved to be reversible during copper depuration. Furthermore, copper exposure induced the development of copper-tolerance, which was partially lost during depuration. It is concluded that bacterial communities exposed to copper contaminated water for a period of 26 days are capable to restore their metabolic attributes after introduction of unpolluted water in aquaria for 28 days.
\end{abstract}

\section{Introduction}

Bacterial communities are susceptible to anthropogenic disturbances like changes in oxygen concentrations and exposure to toxicants. For example, copper has been shown to modify the structure and physiology of bacterial communities. Copper exposure was also shown to change metabolism and induced the development of tolerance to copper in freshwater biofilms (Vymazal, 1984, Barranguet et al., 2002, Barranguet et al., 2003 and Massieux et al., 2004). However, the capability of bacterial communities to recover i.e. to return to the reference situation after toxicant exposure has rarely been investigated (Kelly and Tate, 1998, Griffiths et al., 2001, Kostov and Van Cleemput, 2001 and Kiikkila et al., 2001). 
Species diversity has sometimes been correlated to the capability of complex communities to recover after disturbance. Tilman and Dowing (1994), for instance, observed that the productivity of plant communities resisted disturbances when numerous plant species were present. Similar results were obtained for bacterial communities by Griffiths et al. (2000). They found that physiological recovery from chemical stress was more efficient at high bacterial diversity. Bacterial communities are generally very diverse and a high functional redundancy has been presumed so that communities may recover from a disturbance without losing any attributes (Finlay et al., 1997). However, to functionally recover from a disturbance does not necessarily mean that the community returns to its original species composition.

The present study aimed to test the potential of bacterial communities in freshwater biofilms to recover after copper exposure. Since no single method is available to completely characterize a bacterial community, a combination of methods was applied to obtain a more comprehensive view of community responses to copper stress (Westergaard et al., 2001). Genetic analysis based on denaturing gradient gel electrophoresis (DGGE) and physiological analysis based on community-level physiological profiling (CLPP) were combined with changes in community copper-tolerance, according to the concept of pollution-induced community tolerance (PICT; Blanck et al., 1988).

\section{Materials and methods}

\subsection{Experimental set-up}

Biofilms were grown on glass discs suspended in a ditch of the polder Demmerik in Vinkeveen (The Netherlands: $52^{\circ} 13^{\prime}$ North $4^{\circ} 56^{\prime}$ East) during 4 weeks in April 2002. In total, about 1600 glass discs (each $\approx 1.5 \mathrm{~cm}^{2}$ ) on polyethylene racks (Ivorra et al., 1999) were colonised as well as 16 rectangular glass plates (each $\approx 360 \mathrm{~cm}^{2}$ ). The glass discs were used for abiotic analyses whereas the rectangular glass plates were used for the analysis of community-level physiological profiles (CLPP), denaturing gradient gel electrophoresis (DGGE) and pollution-induced community tolerance (PICT). The colonised discs were transferred to acid pre-rinsed aquaria in the laboratory. Aquaria were filled with filtered water (pore size of $15 \mu \mathrm{m}$ ) from the same ditch of the polder Demmerik to avoid depletion or accumulation of nutrients. The water in the aquaria was renewed every week with water from the ditch. The phosphate concentration was measured once a week (Murphy and Riley, 1962). The phosphate levels was $0.28 \pm 0.29 \mu \mathrm{mol} / \mathrm{l}$, the phosphate concentrations were similar between the copper treatments, but was reduced in time, therefore, weekly water refreshments was needed and performed. The light regime was kept constant during the experiment (light $16 \mathrm{~h}$ : dark $8 \mathrm{~h}$ : light-intensity of $100 \mu \mathrm{mol} \mathrm{m}^{-2} \mathrm{~s}^{-1}$, measured with Li Cor LI-1400 equipped with a Li Cor PAR Sensor) sustaining microbenthic algae in the biofilm. The aquaria were continuously aerated and the temperature was controlled to $20^{\circ} \mathrm{C}$.

Each aquarium contained 42 I of filtered field water, refreshed weekly, two racks, each rack carrying ca. 200 colonised glass discs, and three rectangular glass plates (total biofilm area per aquarium: $\sim 1680 \mathrm{~cm}^{2}$ ). Four aquaria were used, one reference and three copper treated aquaria (nominal concentrations 1, 3 and $10 \mu \mathrm{mol} / \mathrm{l}: \mathrm{CuCl}_{2}$ Tritisol, Merck, Darmstadt, Germany, from a stock solution of $1 \mathrm{~g} / \mathrm{l})$. This period will be further referred to as "the exposure period". After the exposure period, which lasted 26 days, two rectangular plates colonised with biofilms were removed from the copper containing aquaria and the reference aquarium and transferred to acid pre-rinsed aquaria ( $21 \mathrm{I})$. The biofilms were 
incubated for another 28 days in the new non-copper amended water from the field site. This period will be further referred to as "the recovery period".

\subsection{Biofilm harvesting}

The biofilm was harvested from several places on the glass plate using a sterile sharp razor blade (ca. $60 \mathrm{~cm}^{2}$, ca. $4 \%$ of the total biofilm biomass was removed keeping the probability of sampling the same bacterial community low). The samples from each aquarium were pooled in two tubes, one for DGGE and one for CLPP and PICT. For practical reasons, the treatments were not replicated. However, temporal pseudo-replications were made. The biofilms were harvested on several occasions along the experiment: days $0,3,5,12,19,26,33,41$ and 54. Hurlbert (1984) stated that this procedure is proper when the successive dates are not taken as independent replicates of a treatment, which was avoided here.

\subsection{Denaturing gradient gel electrophoresis (DGGE)}

The genetic structure of the bacterial communities of every aquarium was characterised using DGGE. Bacterial specific polymerase chain reaction (PCR)DGGE was performed according to the method described by Muyzer et al. (1993) and further adapted by Massieux et al. (2004). Bacterial specific primers were used, targeting one specific region of the 16S rRNA gene (Muyzer et al., 1993). The DGGE gradient of the denaturing agents, urea and formamide, was ranging from $35 \%$ at the top to $60 \%$ at the bottom of the gel. The gel was submerged in a Tris-acetate-EDTA buffer $(0.5 \times$ TAE $)$ containing $40 \mathrm{mM}$ Tris, $40 \mathrm{mM}$ acetic acid, $1 \mathrm{mM}$ EDTA, pH 7.6 and submitted to $75 \mathrm{~V}$ for $16 \mathrm{~h}$. The DGGE gel was analysed using the relative band intensity (Muylaert et al., 2002) in Phoretix 1D as described in Massieux et al. (2004).

\subsection{Community-level physiological profiles (CLPP)}

Prior to the determination of CLPP and PICT, the harvested biofilm was mixed with $5 \mathrm{ml} \mathrm{BisTris} \mathrm{buffer}\left(10 \mathrm{mM}\right.$; $\left.\mathrm{pH} \mathrm{7;} 4^{\circ} \mathrm{C}\right)$, mixed on a tissue homogeniser $(25,000 \mathrm{rpm})$ and sonicated, 1 pulse of $5 \mathrm{~s}$ (68 watts). The samples were maintained in melting ice. The biofilm suspensions were then centrifuged to remove most algae $(10 \mathrm{~min}$ at $500 \mathrm{~g})$. The optical density of the resulting bacterial suspensions was measured at $750 \mathrm{~nm}$ for every aquarium. This optical density was used to standardise the inoculum size in CLPP determination (ECOplates: BIOLOG Inc. Hayward, USA). Each ECO-plate contains a mineral medium, the tetrazolium redox dye and a set of 31 different carbon substrates plus a control, in triplicates (Garland, 1997). The homogeneous suspensions were transferred to $2 \mathrm{ml}$ plastic tubes that were rapidly frozen in liquid nitrogen, and maintained at $-70^{\circ} \mathrm{C}$ until analysis. These frozen extracts were used for CLPP analysis and PICT determination.

Bacterial dilution series $\left(3^{-1}\right.$ until $3^{-9}$ ) were made to inoculate the ECO-plates. The plates were measured with a spectrophotometer at a wavelength of $590 \mathrm{~nm}$ every $8 \mathrm{~h}$ for 7 days. The plates were incubated in the dark at $20^{\circ} \mathrm{C}$ and a humidity of $\approx 85 \%$. The CLPPs were calculated based on the response in the 31 individual substrates that was corrected for the response of the average colour in the plate (AWCD: average well colour development) according to the procedure described by Van Elsas et al. (in press) and Boivin et al. (2005). 
The number of substrates being utilised per heterotrophic bacterial community was calculated by counting the wells with a higher colour formation than 0.3 (absorbance at $590 \mathrm{~nm}$ after 7 days of incubation).

To survey the activity of the bacterial community in the ECO-plate, the AWCD was calculated after 3 days incubation. This AWCD was given per biofilm surface (AWCD abs $/ \mathrm{cm}^{2}$ ).

Simultaneously with CLPP determination the number of colony forming units (CFUs) in the standardised sample was determined by plating on Tryptone Soya Broth agar $(0.3 \mathrm{~g} / \mathrm{l})$ and calculated per unit of biofilm surface $\left(\mathrm{cm}^{2}\right)$. The agar plates were incubated in the dark at $25^{\circ} \mathrm{C}$ for a period of 8 days.

\subsection{Determination of bacterial PICT}

The frozen bacterial suspensions were thawed and diluted in buffer (BisTris; $\mathrm{pH} 7$; $100 \mathrm{mM}$ ) to an activity equivalent to an AWCD of 0.8 abs at $590 \mathrm{~nm}$ after 7 days of incubation in ECO-plates at $20^{\circ} \mathrm{C}$. Precise inoculum standardization is necessary because the PICT response is dependent on inoculum density (Van Beelen et al., 2004). These diluted bacterial suspensions were exposed to $\mathrm{CuCl}_{2}$ $(0,0.2,0.5,2,5,20,50,160,470,1570 \mu \mathrm{mol} / \mathrm{l})$ for $4 \mathrm{~h}$ at $20^{\circ} \mathrm{C}$. Subsequently, the copper-exposed suspensions were inoculated in BIOLOG ${ }^{\circledR}$ GN2 plates $(100 \mu \mathrm{l}$ per well). These plates contain a mineral medium, the tetrazolium redox dye and a set of 95 different carbon substrates plus a control (no carbon).

The highest colour development after 7 days of incubation was used for quantification of the microbial response and subsequently for calculation of the $\mathrm{EC}_{50}$-values. The $\mathrm{EC}_{50}$-values were calculated by fitting the data with a log normal sigmoidal curve, using a non-linear regression (GraphPad Prism, version 2.01, June 1996) (Boivin et al., 2005). Based on previous investigations at our laboratory, $\mathrm{EC}_{50}$-values with a standard error lower than 2 and a correlation coefficient higher than 0.5 were found appropriate limits for the calculation of PICT.

Cumulative sensitivity distributions of the bacterial communities, so-called substrates-utilization sensitivity distributions (SuSDs), were constructed using the $\mathrm{EC}_{50}$, well fitted. From these SuSDs, a median was calculated using GraphPad Prism and given as $a$ SuSD (median ( $\left(\mathrm{EC}_{50}\right.$, well fitted)). PICT is present if the $a$ SuSD significantly increases when incubated in the presence of increased toxicant concentrations.

\subsection{Determination of copper concentrations}

An aliquot of $1 \mathrm{ml}$ of water (filtered and unfiltered) was taken in triplicates from every aquarium before and after $\mathrm{Cu}$ was added during the exposure period and before and after the water was refreshed during the recovery period. An aliquot of $1 \mathrm{ml}$ of water was acidified with $30 \mu \mathrm{HNO} \mathrm{HN}_{3}$ (65\% p.a. Merck). Three glass discs per treatment were sampled every week for metal analysis. Biofilm samples were freeze-dried over night and $1 \mathrm{ml}$ of $65 \% \mathrm{HNO}_{3}$ was added to the samples, which were kept at room temperature for 2 days. The samples were then centrifuged at $10,000 \mathrm{~g}$ for $5 \mathrm{~min}$ to remove suspended particles. Water and biofilm samples were measured on a flame atomic absorption spectrophotometer (AAS; Perkin Elmer 110B, Boston, USA; detection limit $50 \mu \mathrm{g} / \mathrm{I})$. Samples with a concentration lower than $80 \mu \mathrm{g} / \mathrm{I}$ were determined on an AAS graphite furnace (Perking Elmer, 5100 PC, Boston, USA; with background correction, detection limit $3 \mu \mathrm{g} / \mathrm{l})$. 


\subsection{Statistics}

The shifts between bacterial communities determined with DGGE profiling were graphically represented in a non-parametric multi-dimensional scaling ordination (NMDS), which represents the matching similarities calculated in a triangular matrix of similarity coefficients computed between every pair of samples (Clarke and Warwick, 1998). The shifts observed in the NMDS representation were assessed using the analysis of the similarity functions (ANOSIM) within the Primer 5 software package.

Multivariate analysis was applied to analyse the changes in CLPPs between the different bacterial communities using the software package Canoco V.4.0 (CPRODLO, Wageningen, The Netherlands). The CLPPs were first analysed with a detrended component analysis (DCA). The length of gradient (based on DCA) was lower than 3 (Van Wijngaarden et al., 1995) and therefore the different samples were collated in a redundancy analysis (RDA) using sampling day in the aquaria as a covariable. Subsequently, principal response curves (PRC) were made (Van den Brink et al., 1999). For each time point the effect of copper treatments on the bacterial communities was calculated relative to its reference $(0 \mu \mathrm{mol} / \mathrm{l} \mathrm{Cu})$. Therewith the variation of copper-exposed bacterial communities in relation to the reference (the vertical axis) is plotted versus time (horizontal axis). The explained variation in the PRC is given by the eigenvalue. The influence of copper on differences in CLPPs of the different bacterial communities was tested taking the biofilm copper concentrations as a continuous variable using a Monte Carlo permutation test in an RDA. To test for significance of copper: 9999 permutations were performed and a significance level of 0.05 was chosen. Unfortunately, the sample from $1 \mu \mathrm{mol} / \mathrm{l}$ treatment sampled on day 54 is not shown. Due to a manipulation error the sample was discarded from the analysis.

A one-way ANOVA was used to statistically compare the AWCD and the number of CFUs between the different sampling dates and between the different treatments (copper and temperature).

To test the significance of the $a$ SuSD shifts, one-way ANOVA was performed (data were assumed to be normally distributed and the variance independent). Because more than two samples were compared, a Bonferroni correction was applied. In a Bonferroni correction, the $a$ level is adjusted downward and to consider chance capitalization more comparisons are made.

A one-way ANOVA was used to statistically compare the copper concentration in the water and in the biofilm between the different sampling days and between the different copper treatments.

\section{Results}

\subsection{Copper accumulation in the biofilm}

Ditch water and biofilms grown in the ditch contained, respectively, $0.11 \pm 0.09 \mu \mathrm{mol} / \mathrm{l}$ and $0.05 \pm 0.04 \mu \mathrm{g}$ copper $/ \mathrm{mg}$ per dry weight biofilm. Copper concentration in biofilms on the glass plates stabilized at levels of $98.5 \pm 22.5$, $15.6 \pm 1.9$ and $3.8 \pm 1.2 \mu \mathrm{mol} / \mathrm{g}$ DW during exposure to actual copper concentrations of, respectively, $6.8 \pm 2.0,2.1 \pm 0.7$ and $0.6 \pm 0.2 \mu \mathrm{mol} / \mathrm{l}$ in the water (Fig. 1). This accumulation of copper in the biofilms was roughly proportional to the concentration in the water. The copper concentration in the biofilm exposed to $6.8 \mu \mathrm{mol} / \mathrm{l}$ copper decreased from $120 \pm 0.01 \mu \mathrm{mol} / \mathrm{g} \mathrm{DW}$ at the beginning of the recovery period (day 26 ) to $25.5 \pm 3.8 \mu \mathrm{mol} / \mathrm{g} \mathrm{DW}$ at the 
end of the period (day 54). Therewith, the copper concentration in the copperexposed biofilm at the end of the recovery period was still 25 times higher than the copper concentration in the reference biofilm, indicating that four water refreshments were not sufficient to allow for a complete biofilm copper depuration. Similar trends were observed in the other treatments. To exclude any release of copper from the aquaria walls, clean aquaria were used during the recovery period.
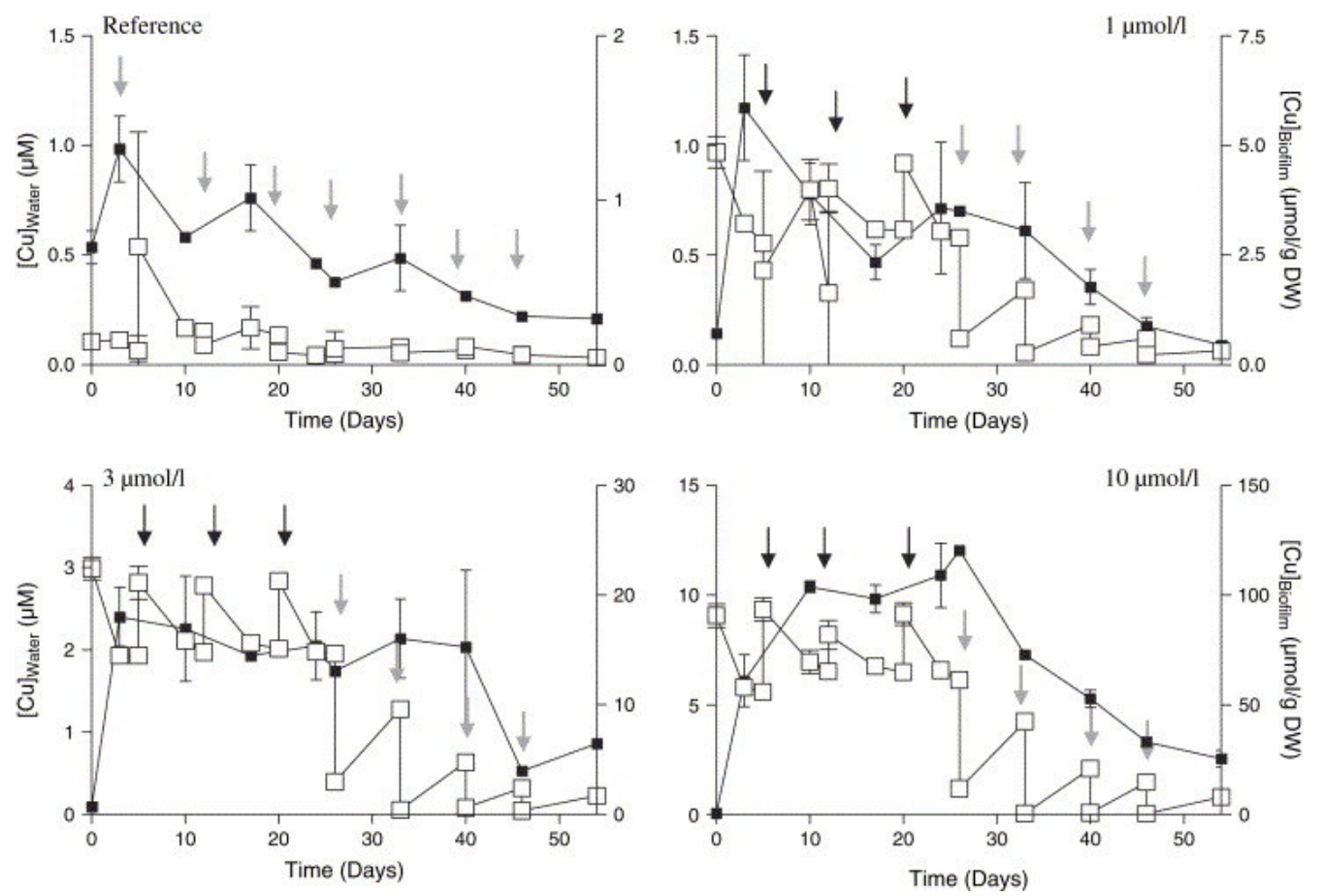

Fig. 1. Actual copper concentrations in four aquaria following regular additions of copper (total nominal concentrations: 1,3 and $10 \mu \mathrm{mol} / \mathrm{l}$, and a reference). Open symbols: copper concentrations in water $(\mu \mathrm{mol} / \mathrm{l})$. Closed symbols: copper concentrations in the biofilms ( $\mu \mathrm{mol} / \mathrm{g} \mathrm{DW})$. Black arrows indicate copper containing water refreshments. Grey arrows indicate water refreshment without copper. Error bars indicate standard deviations.

\subsection{Denaturing gradient gel electrophoresis (DGGE)}

Fig. 2 shows the results of the analysis of similarities between DGGE patterns observed for the different biofilms expressed in a non-parametric multidimensional analysis (NMDS: stress factor $=0.08$ ). The composition of bacterial communities changed over time in all aquaria. In addition, during the exposure period, the bacterial community from the most polluted biofilm (exposed to $6.8 \mu \mathrm{mol} / \mathrm{l} \mathrm{Cu})$ had a significantly different banding pattern $(p=0.03)$ from the bacterial communities in the reference, 0.6 and $2.1 \mu \mathrm{mol} / \mathrm{l}$ copper-exposed biofilms. Fewer and different bands were present in the community exposed to the highest copper concentration. These differences were more obvious during prolonged incubation. In conclusion, the aquaria treated with $6.8 \mu \mathrm{mol} / \mathrm{l}$ copper showed the largest deviation from the control aquarium with respect to the structure of the microbial community. 


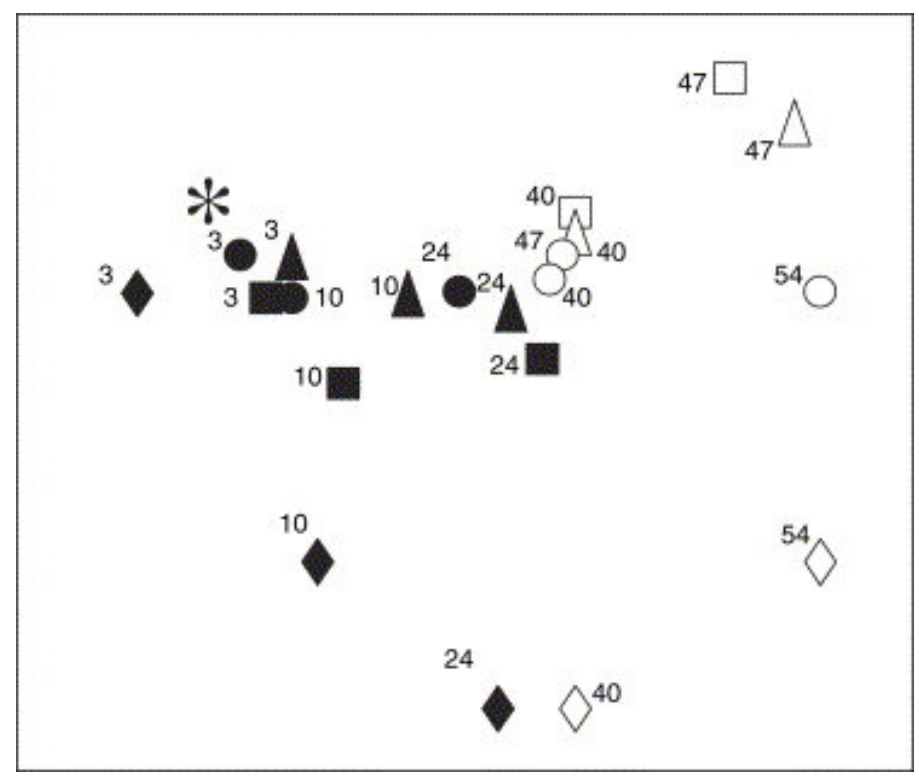

Fig. 2. Non-metric multi-dimensional scaling (MDS) of denaturing gradient gel electrophoresis (DGGE) of biofilm samples from different aquaria. The asterisk represents the biofilm collected from glass plates in the ditch (field situation). Copper treatments: reference $(\bullet), 1 \mu \mathrm{mol} / \mathrm{I} \mathrm{Cu}(\boldsymbol{\Delta}), 3 \mu \mathrm{mol} / \mathrm{l} \mathrm{Cu}(\boldsymbol{\bullet})$ and $10 \mu \mathrm{mol} / \mathrm{I} \mathrm{Cu}(\bullet)$, respectively. The sampling day is written beside each symbol. Closed symbols represent the exposure period. Open symbols represent the recovery period.

Fewer and different bands were still present in the community exposed to $6.8 \mu \mathrm{mol} / \mathrm{l}$ copper compared to the other treatments. During the recovery period the structure of the bacterial community from the $6.8 \mu \mathrm{mol} / \mathrm{l}$ copper biofilm was still significantly different (ANOSIM: $p>0.5$ ) from that in the other three aquaria that were treated with $0.6,2.1 \mu \mathrm{mol} / \mathrm{l}$ copper and the reference. Assuming that the differences between aquaria are caused by the different treatment levels of copper it is concluded that exposure to $6.8 \mu \mathrm{mol} / \mathrm{I}$ copper provoked distinct changes in DGGE profiles of bacterial consortia, which under the given experimental conditions did not reverse upon weekly addition of unpolluted water.

\subsection{Community-level physiological profiles (CLPP)}

Fig. 3 represents CLPP shifts expressed in principal response curves (PRC). The first part of the PRC represents the copper exposure period (days 0-26) whereas the second part represents the recovery period (days 26-54). A decrease in the canonical coefficient corresponds to fewer substrates used or to limited carbonsource utilization than used in the reference. After 12 days of exposure to 2.1 and $6.8 \mu \mathrm{mol} / \mathrm{l}$ copper, bacterial communities differed the strongest from the reference. These differences were maintained until day $33(p=0.008)$. 


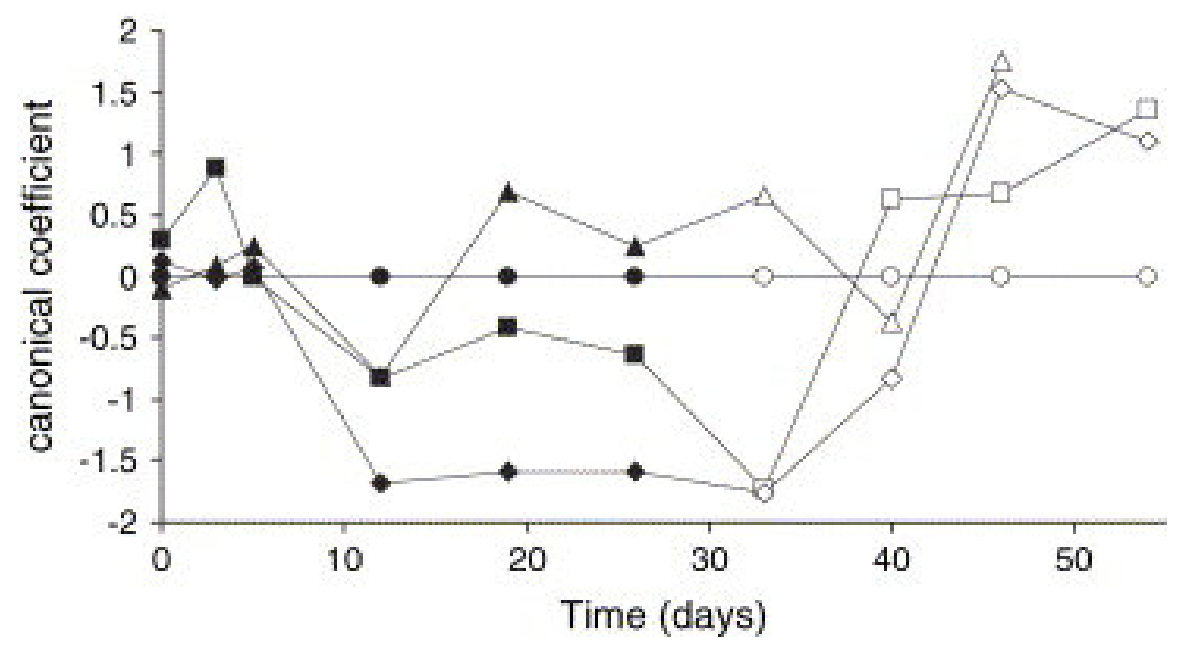

Fig. 3. Principal response curves (PRC) of community-level physiological profiles (CLPP) of aquatic bacterial communities from several biofilms. From days 0 until 26, the biofilms were exposed to different copper concentrations and from days 26 until 54 all the aquaria were refreshed with ditch water without copper addition. Closed symbols represent the exposure period. Open symbols represent the recovery period. Copper treatments: $0 \mu \mathrm{mol} / \mathrm{l} \mathrm{Cu}(\bullet), 1 \mu \mathrm{mol} / \mathrm{l} \mathrm{Cu}(\boldsymbol{\Lambda})$, $3 \mu \mathrm{mol} / \mathrm{l} \mathrm{Cu}(\mathbf{-})$ and $10 \mu \mathrm{mol} / \mathrm{l} \mathrm{Cu}(\bullet)$, respectively.

Based on Monte Carlo permutation test, the first axis of the PRC explains $11 \%$ of the variation between the different bacterial communities and the differences between the bacterial communities explained in the PRC were significant $(p=0.006)$. The decrease in the canonical coefficient associated with different metabolic profiles were primarily due to lower utilization of $\beta$-methyl-D-glucoside, D-xylose, a-cyclodextrin, glycyl-L-glutamic acid, glucose-1-phosphate, D,L-aglycerol phosphate, and a higher utilization of I-erythritol, 2-hydroxy benzoic acid, 4-hydroxy benzoic acid, glycogen and a-keto butyric acid by the bacterial community exposed to copper. During the recovery period the metabolic profiles of the bacterial communities from 2.1 to $6.8 \mu \mathrm{mol} / \mathrm{l}$ copper tended to converge towards the reference. At the end of the recovery period, differences in the metabolic profiles between the individual aquaria were not statistically significant (Monte Carlo permutation: $p=0.66$ ). A more uniform substrate utilization profile among the bacterial communities of the different treatments was the cause of this similarity. Assuming that the differences between aquaria are primarily caused by the different exposure concentrations of copper, it seems that copper had a significant effect on the metabolic profiles up to $6.8 \mu \mathrm{mol} / \mathrm{l}$, but that during a recovery period, these effects disappeared, and finally the metabolic profiles of the communities were not statistically different any more from every copper treatment, and bacterial communities could utilize more similar carbon sources at the end of the recovery period than at the end of the exposure period.

During incubation of the biofilms on glass plates in the aquaria, the number of colony forming units (CFUs) stayed constant $\left(6.5 \pm 0.5 \mathrm{log} \mathrm{CFUs} / \mathrm{cm}^{2}\right.$; mean of all aquaria on every sampling points; $n=36$ ) and the average well colour development (AWCD) in the ECO-plates decreased significantly in all bacterial communities (AWCD abs/ $\mathrm{cm}^{2}$ decreased from $1.1 \pm 0.3$ to $0.5 \pm 0.3 ; p<0.01$; mean of all aquaria on every sampling points; $n=36$ ). The numbers of CFUs and the AWCD in the ECO-plates, respectively, $6.3 \pm 0.5 \mathrm{log} \mathrm{CFUs} / \mathrm{cm}^{2}$ (mean of the reference, 0.6 and $2.1 \mu \mathrm{mol} / \mathrm{l}$ on every sampling points; $n=27$ ) and $0.8 \pm 0.3 \mathrm{abs} / \mathrm{cm}^{2}$ (mean of the reference, 0.6 and $2.1 \mu \mathrm{mol} / \mathrm{l}$ on every sampling points; $n=27$ ) did not show significant differences under the given experimental 
conditions between bacterial communities exposed to the reference, 0.6 and $2.1 \mu \mathrm{mol} / \mathrm{l}$ copper. However, the sub-samples $(n=9)$ of the bacterial communities exposed to $6.8 \mu \mathrm{mol} / \mathrm{l}$ copper had a lower AWCD (AWCD abs $/ \mathrm{cm}^{2}$ was $0.4 \pm 0.1 ; p=0.03)$, and a higher number of CFUs $(7.4 \pm 0.3 ; p=0.02)$ than the sub-samples taken from the aquaria that were treated with other $\mathrm{Cu}$ concentrations. During the recovery period, the number of CFUs of the bacterial communities exposed to $6.8 \mu \mathrm{mol} / \mathrm{l}$ copper stayed higher and the AWCD stayed lower than the other treatments. Therefore, while the number of CFUs increased in the presence of $6.8 \mu \mathrm{mol} / \mathrm{l}$ copper, the activity of the bacteria, based on AWCD measurements, decreased. Those differences in bacterial biomass and activity were maintained until the end of the experiment (day 54).

\subsection{Pollution-induced community tolerance (PICT)}

Tolerance characteristics for copper were determined using multi-well plates, allowing the construction of substrates-utilization sensitivity distributions (SuSDs) based on numerous $\mathrm{EC}_{50}$-values. In Fig. 4, the copper-tolerance of the different bacterial communities is shown. The bacterial communities from the reference aquarium showed variable copper-tolerance in time ( $a$ SuSD rising from 1.3 to $3.0 \mathrm{mg} / \mathrm{l}$ ). However, $a$ SuSDs were always higher for copper treated bacterial communities than for the reference. After 12 days exposure to $6.8 \mu \mathrm{mol} / \mathrm{l}$ copper, the bacterial community showed an increase in tolerance compared to the reference $a$ SuSD increased from 1.7 to $6.7 \mathrm{mg} / \mathrm{l}$. Bacteria from the copper treated biofilms $(0.6,2.1$ and $6.8 \mu \mathrm{mol} / \mathrm{l} \mathrm{Cu})$ showed a significantly higher $a$ SuSD after 26 days of incubation, indicating an increased copper-tolerance. The highest tolerance for copper was reached after 26 days of incubation for all copper treatments. Copper-tolerance for all copper treatments $(0.6,2.1$ and $6.8 \mu \mathrm{mol} / \mathrm{l}$ ) had clearly decreased on days 41 and 54, respectively, after 2 and 4 weeks of depuration.

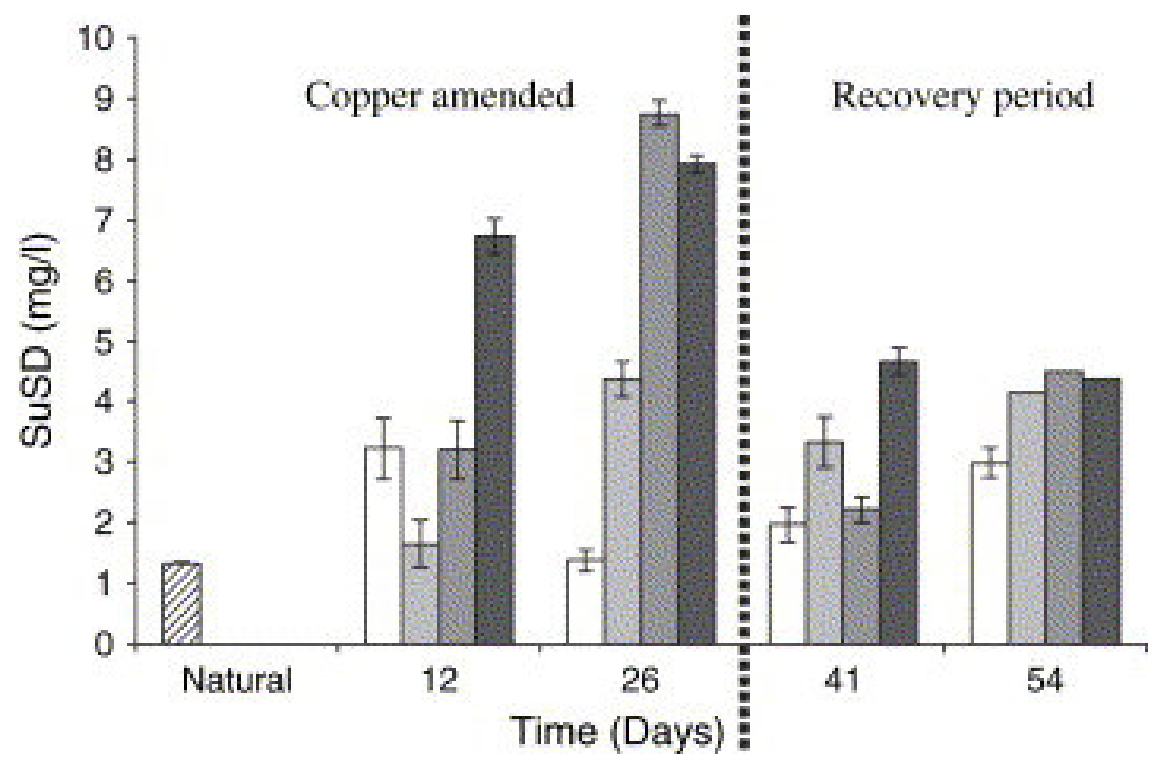

Fig. 4. The median of the substrates-utilization sensitivity distribution ( $a$ SuSD $\mathrm{mg} / \mathrm{l}$ ) of aquatic bacterial communities from biofilms exposed to different copper concentrations; $0 \mu \mathrm{mol} / / \mathrm{Cu}$ : white bars, $1 \mu \mathrm{mol} / / \mathrm{Cu}$ : light grey bars, $3 \mu \mathrm{mol} / \mathrm{l}$ $\mathrm{Cu}$ : dark grey bars and $10 \mu \mathrm{mol} / \mathrm{l} \mathrm{Cu}$ : black bars. The error bars represent $95 \%$ confidence intervals. 


\section{Discussion}

In the present study the potential of bacterial communities in freshwater biofilms to recover after copper exposure was investigated. Also, the importance of comparing results with different techniques that described genetic and physiological structure was stressed (Westergaard et al., 2001). DGGE and CLPP shifts in bacterial communities were shown to correlate with copper exposure concentrations in the aquaria. Assuming that these shifts are primarily caused by the different copper exposures in the aquaria it appears that only physiological traits based on the CLPP shifts recovered from copper exposure. The observation is consistent with the conclusions of Finlay et al. (1997) on the diversity of bacterial taxa, demonstrating a high level of redundancy in bacterial communities that allows these communities to adapt to new conditions.

Assuming that changes between aquaria are primarily caused by differences in copper exposure, it seems that the copper-induced successional changes during the exposure period remained present in the recovery period despite bacterial reinoculation via water refreshments using natural surface water. This regular bacterial re-inoculation did not break-up genetic differences between bacterial communities that developed differently in the various copper treatments. One could expect that bacterial communities from biofilms exposed to the different copper treatments would regain their uniform genetic structure more quickly when bacterial communities are re-inoculated to the system during the recovery period via natural surface water. Several explanations may be brought forward explaining the maintained genetic differences. First, autotrophic microorganisms that dominated the biofilm exposed to copper also stayed visually distinct from the reference situation. Because a close relationship is expected between autotrophic and heterotrophic microorganisms (Romani et al., 2004), persistent differences of bacterial community composition could theoretically be maintained via long lasting effects of copper on the autotrophic microorganisms that dominated the biofilm (Massieux et al., 2004). Second, the so-called founder effect. Indeed it might be arduous to invade an established community than a pioneer community. And third, the copper concentrations in the biofilm remained relatively high after 28 days of recovery. In the highest copper treatment, the copper concentration after 28 days of recovery was $25 \mu \mathrm{mol} / \mathrm{g}$, therefore the bacterial communities were still exposed to copper despite the weekly water refreshment.

The metabolic profiles of bacterial communities were significantly different upon copper exposure, but these differences were lost after depuration. Genetically different consortia were found to sustain a similar capacity to use carbon substrates. Griffiths et al. (2000) observed functional recovery of bacterial communities after a heat shock while the structure of the bacterial communities, based on DGGE analysis remained different. Griffiths et al. (2000) induced differences in bacterial community diversity by fumigation. Two months after a heat shock, all treated and untreated bacterial communities could utilize grass residue to the same extent. However, in that study, the bacterial communities could not utilize grass residue to the same extent after a persistent copper stress. Kiikkila et al. (2001) made similar conclusions after studying copper-exposed microbial communities using phospholipids fatty acid analysis (PLFA). The PLFA profiles did not change towards the unpolluted site after copper availability was reduced. However, the community that had developed in the presence of copper seemed to have lost its copper-tolerance, tested with $\left[{ }^{3} \mathrm{H}\right]$-thymidine incorporation, when copper availability decreased after mulch addition. 
The physiological parameters that were determined in the present study are based on the use of BIOLOG ${ }^{\circledR}$ plates. These plates support primarily the fast growing, cultivable bacteria whereas DGGE focuses on dominant genotypes (Verschuere et al., 1997 and Smalla et al., 1998). Therefore, these different techniques highlight different parts of the bacterial community, potentially providing a more complete image than would be obtained using only one technique.

The present experiment did not show a complete loss of tolerance after the recovery period, but a plausible reason for this may be the incomplete release of copper bound to the biofilm, in combination with a restricted time for recovery. Yet, both the induction and the decrease of community tolerance were evident. Also, the $a$ SuSD values found for terrestrial bacterial communities exposed to copper were in the same range as the ones found in clean soils ( $a$ SuSD $3 \mathrm{mg} / \mathrm{l}$ ) and polluted soils ( $a$ SuSD $8 \mathrm{mg} / \mathrm{l}$ ) using the same technique (Van Beelen et al., 2004). During the exposure phase and the depuration phase, Biolog-PICT could not be directly explained by genetic changes. Genetically different communities can have similar tolerance for a contaminant for the same reasons as these may be capable to use the same carbon substrates. Therefore, in view of our results, it seems that the exposure to a contaminant determined the level of tolerance to that contaminant and not the community composition.

\section{Conclusion}

After copper exposure, heterotrophic bacterial communities functionally recovered after copper exposure when determining the utilization of simple carbon substrates from Biolog plates. However, DGGE banding patterns of bacterial communities of aquatic photosynthesizing biofilms did not recover after copper exposure. This indicates that genetically different bacterial communities can sustain similar primary functions and have similar tolerance to a contaminant.

\section{Acknowledgments}

We thank Christiane Barranguet, Jenny Langenskiöld, Frank Swartjes and Patrick van Beelen for their useful input. We also thank Willem Roelofs for his great help in building a macro to treat the data. We also thank the Dutch organisation for scientific research (NWO), the stimulation program on system-oriented ecotoxicological research (SSEO), and the Dutch National Institute for Public Health and the Environment (RIVM) for funding the project under number 0123.060/061 (NWO/SSEO) and project number M/860711 (RIVM). 


\section{References}

Barranguet et al., 2002 C. Barranguet, M. Plans, E. Van der Grinten, J.J. Sinke and W. Admiraal, Development of photosynthetic biofilms affected by dissolved and sorbed copper in a eutrophic river, Environmental Toxicology and Chemistry 21 (2002), pp. 1955-1965.

Barranguet et al., 2003 C. Barranguet, F.P. Van den Ende, M. Rutgers, A.M. Breure, M. Greijdanus, J.J. Sinke and W. Admiraal, Copper-induced modifications of the trophic relations in riverine algalbacterial biofilms, Environmental Toxicology and Chemistry 22 (2003), pp. 1340-1349.

Blanck et al., 1988 H. Blanck, S.A. Wängberg and S. Molander, Pollution-induced community tolerance. A new ecotoxicological tool. In: J.J. Cairns and J.R. Pratt, Editors, Functional Testing of Aquatic Biota for Estimating Hazards of Chemicals (1988), pp. 219-230 (ASTM STP 988).

Boivin et al., 2005 M.E.Y. Boivin, B. Massieux, A.M. Breure, F.P. Van den Ende, G.D. Greve, M. Rutgers and W. Admiraal, Effects of copper and temperature on structural and functional traits of aquatic bacterial communities, Aquatic Toxicology 71 (2005), pp. 345-356.

Clarke and Warwick, 1998 K.R. Clarke and R.M. Warwick, Quantifying structural redundancy in ecological communities, Oecologia 113 (1998), pp. 278-289.

Finlay et al., 1997 B.J. Finlay, C. Maberly and J.I. Cooper, Microbial diversity and ecosystem function, Oikos 80 (1997), pp. 209-213.

Garland, 1997 J.L. Garland, Analysis and interpretation of community-level physiological profiles in microbial ecology, FEMS Microbiol Ecology 24 (1997), pp. 289-300.

Griffiths et al., 2000 B.S. Griffiths, K. Ritz, R.D. Bardgett, R. Cook, S. Christensen, F. Ekelund, S.J. Sorensen, E. Baath, J. Bloem, P.C. de Ruiter, J. Dolfing and B. Nicolardot, Ecosystem response of pasture soil communities to fumigation-induced microbial diversity reductions: an examination of the biodiversity-ecosystem function relationship, Oikos 90 (2000), pp. 279-294.

Griffiths et al., 2001 B.S. Griffiths, K. Ritz, R. Wheatley, H.L. Kuan, B. Boag, S. Christensen, F. Ekelund, S.J. Sorensen, S. Muller and J. Bloem, An examination of the biodiversity-ecosystem function relationship in arable soil microbial communities, Soil Biology and Biochemistry 33 (2001), pp. 17131722 .

Hurlbert, 1984 S.H. Hurlbert, Pseudoreplication and the design of ecological field experiments, Ecological Monographs 54 (1984), pp. 187-211.

Ivorra et al., 1999 N. Ivorra, J. Hettelaar, G.M.J. Tubbing, M.H.S. Kraak, S. Sabater and W. Admiraal, Translocation of microbenthic algal assemblages used for in situ analysis of metal pollution in rivers, Archives of Environmental Contamination and Toxicology 37 (1999), pp. 19-28.

Kelly and Tate, 1998 J.J. Kelly and R.L. Tate, Effects of heavy metal contamination and remediation on soil microbial communities in the vicinity of a zinc smelter, Journal of Environmental Quality 27 (1998), pp. 609-617.

Kiikkila et al., 2001 O. Kiikkila, J. Perkiomaki, M. Barnette, J. Derome, T. Pennanen, E. Tulisalo and H. Fritze, In situ bioremediation through mulching of soil polluted by a copper-nickel smelter, Journal of Environmental Quality 30 (2001), pp. 1134-1143.

Kostov and Van Cleemput, 2001 O. Kostov and O. Van Cleemput, Microbial activity of Cu contaminated soils and effect of lime and compost on soil resiliency, Compost Science and Utilization 9 (2001), pp. 336-351.

Massieux et al., 2004 B. Massieux, M.E.Y. Boivin, F.P. Van den Ende, J. Langenskiöld, P. Marvan, C. Barranguet, W. Admiraal, H.J. Laanbroek and G. Zwart, Analysing structural and physiological profiles to assess the effect of $\mathrm{Cu}$ on biofilm forming microbial communities, Applied Environmental Microbiology 70 (2004), pp. 4512-4521.

Murphy and Riley, 1962 J. Murphy and J.P. Riley, A modified single solution method for the determination of phosphate in natural waters, Analytic Chemistry 27 (1962), pp. 31-36. 
Muylaert et al., 2002 K. Muylaert, K. Van der Gucht, N. Vloemans, L. De Meester, M. Gillis and N. Vyverman, Relationship between bacterial community composition and bottom-up versus top-down variables in four eutrophic shallow lakes, Applied Environmental Microbiology 68 (2002), pp. 47404750 .

Muyzer et al., 1993 G. Muyzer, E.C. Dewaal and A.G. Uitterlinden, Profiling of complex microbialpopulations by denaturing gradient gel electrophoresis analysis of polymerase chain reaction-amplified genes coding for $16 \mathrm{~S}$ ribosomal-RNA, Applied Environmental Microbiology 59 (1993), pp. 695-700.

Romani et al., 2004 A.M. Romani, H. Guasch, I. Munoz, J. Ruana, E. Vilalta, T. Schwartz, F. Emtiazi and S. Sabater, Biofilm structure and function and possible implications for riverine DOC dynamics, Microbial Ecology 47 (2004), pp. 316-328.

Smalla et al., 1998 K. Smalla, U. Wachtendorf, H. Heuer, W.T. Liu and L. Forney, Analysis of biolog GN substrate utilization patterns by microbial communities, Applied Environmental Microbiology 64 (1998), pp. 1220-1225.

Tilman and Dowing, 1994 D. Tilman and J.A. Dowing, Biodiversity and stability in grasslands, Nature 367 (1994), pp. 363-365.

Van Beelen et al., 2004 P. Van Beelen, M. Wouterse, L. Posthuma and M. Rutgers, Location-specific ecotoxicological risk assessment of metal-polluted soils, Environmental Toxicology and Chemistry 23 (2004), pp. 2769-2779.

Van den Brink et al., 1999 P.J. Van den Brink, R.P.A. Van Wijngaarden, W.G.H. Lucassen, T.C.M. Brock and P. Leeuwangh, Principal response curve: analysis of time-dependent multivariate responses of community to stress, Environmental Toxicology and Chemistry 18 (1999), pp. 138-148.

Van Elsas et al., in press Van Elsas, J.D., Top, E.M., Smalla, K., Breure, A.M., Insam, H., Pälojarvi, A., Rutgers, M. Soil microbial diversity and community structure. In: Bloem, J., Hopkin, S.P., Benedetti, A. (Eds.), CAB International, Microbiological Methods for Assessing Soil Quality, in press.

Van Wijngaarden et al., 1995 R.P.A. Van Wijngaarden, P.J. Van den Brink, J.H. Oude Voshaar and P. Leeuwangh, Ordination techniques for analyzing response of biological communities to toxic stress in experimental ecosystems, Ecotoxicology 4 (1995), pp. 61-77.

Verschuere et al., 1997 L. Verschuere, V. Fievez, L. Van Vooren and W. Verstraete, The contribution of individual populations to the Biolog pattern of model microbial communities, FEMS Microbial Ecology 24 (1997), pp. 353-362.

Vymazal, 1984 J. Vymazal, Short-term uptake of heavy metals by periphyton algae, Hydrobiologia 119 (1984), pp. 171-179.

Westergaard et al., 2001 K. Westergaard, A.K. Muller, S. Christensen, J. Bloem and S.J. Sorensen, Effects of tylosin as a disturbance on the soil microbial community, Soil Biology and Biochemistry 33 (2001), pp. 2061-2071. 